\title{
A Study on the Correlation between Social Class and Life Satisfaction Perceived by the Korean Elderly
}

\author{
Myung-Hee JUNG ${ }^{1}$
}

Received: April 01, 2020 Revised: May 17, 2020 Accepted: June 08, 2020

\begin{abstract}
The purpose of this study is to analyze the effects of subjective class consciousness on life satisfaction. This research aimed to not only analyze the relative explanatory power, but also the influence of satisfaction of life within the socioeconomic status where the elderly consider themselves to be an integral part. The elderly's satisfaction in life was analyzed in comparison with demographic characteristics such as gender and age. The correlations of objective socioeconomic characteristics such as income level and education level were also observed. For this purpose, the Korea Labor Panel 17th data (2014) was used to conduct a one-way batch distribution analysis and a hierarchical regression analysis. It was seen that there was a correlation in the Korean elderly in terms of class consciousness and life satisfaction. The elderly with a lower subjective class consciousness showed lower life satisfaction. The relative influences were stronger than the demographic and socioeconomic characteristics of the elderly, and the explanatory power was much higher than the objective income levels. These results show that the subjective perception of their socioeconomic status has a significant influence on the level of life satisfaction of the Korean elderly, independent of the objective income level.
\end{abstract}

Keywords : Elderly, Life Satisfaction, Subjective Class Consciousness, Demographic Characteristics, Socioeconomic Characteristics

JEL Classification Code: I00, I30, I31

\section{Introduction}

In Korea, as the aging population progresses rapidly, the problem of the elderly is emerging. The suicide and poverty rate for the elderly are among the highest compared to the other OECD countries. As of 2016, the suicide rate of the elderly aged 65 and over was 54.8 per 100,000 people, the highest among the OECD member countries since 2009. The suicide rate of the elderly is high, reaching 3.2 times the average of member countries (OECD, 2017). Also, the relative poverty rate of the elderly is $46.7 \%$, which is also the highest among the OECD member countries (Yoon \& Kim, 2008). The satisfaction level of the Korean elderly is very low, and the loneliness and depression of the elderly is

${ }^{1}$ First Author and Corresponding Author. Professor, Department of Social Welfare, Jungwon University, Korea [Postal Address: 85 Munmu-ro, Goesan-eup, Goesan-kun, Chungbuk, 28024, Korea] Email: jmhsubject@hanmail.net

(c) Copyright: The Author(s)

This is an Open Access article distributed under the terms of the Creative Commons Attribution Non-Commercial License (http://Creativecommons.org/licenses/by-nc/4.0/) which permits unrestricted noncommercial use, distribution, and reproduction in any medium, provided the original work is properly cited. a serious problem that needs to be addressed. The percentage of respondents who were satisfied with their lives fell in their 20s $(75.6 \%), 30 \mathrm{~s}(73.3 \%), 40 \mathrm{~s}(69.0 \%), 50 \mathrm{~s}(63.6 \%)$, and $60 \mathrm{~s}(59.4 \%)$. This is in contrast to other developed countries, where life satisfaction is lowered in their 40s and 50s, and then rises again in old age, indicating that the psychological well-being of the Korean elderly is at an all-time low (Kim et al., 2016). In this situation, raising the satisfaction and quality of life for the elderly population is emerging as an important task.

Subjective Social Status (SSS) is drawing attention as an important determinant of mental and physical wellbeing. The lower the perceived subjective class, the more stressed and vulnerable the disease appears. Subjective hierarchy is strongly associated with various physical and mental health indicators, including depression, subjective health, chronic disease and hypertension (Adler et al., 2008; Franzini \& Fernandez-Escquer, 2006; Ghaed \& Gallo, 2007; Hu et al., 2005). The correlation between subjective class consciousness and various health indicators persists after accounting for traditional socio-economic status, such as education, income and occupation, and sometimes predicts health outcomes more robustly and strongly than 
objective socioeconomic statuses (Adler et al., 2008; Singh et al., 2005). Awareness of relative positions in the social hierarchy determines whether the need for recognition is met. Therefore, subjective class consciousness is reported to be associated with mental health.

This phenomenon can be explained by the social comparison theory. According to the theory of social comparison, an individual evaluates his situation by comparing himself with a plurality of reference groups with various motives (Jang, 2009; Ryu, 2015). American economist Easterlin had earlier concluded that relative incomes compared to others, rather than absolute increases or decreases, are more important to happiness (Easterlin, 1974). Based on this pioneering research, studies have steadily accumulated showing it is very important for the subjective quality of life that the individual sets the reference group through social comparison. Individuals make comparisons based on those who are superior to, similar to, or lacking in their own population, and often compare themselves with their neighbors and acquaintances in common areas, peers of similar education and occupations, and the ideals of the media (Fernandez \& Kulik, 1981; Ferrer-i-Carbonell, 2005; Luttmer, 2005; Kang, 2010; Lee \& Hong, 2012).

Among them, those who have a high standard and also underestimate their own standard of living have relatively low subjective happiness (Clark \& Senik, 2010). Applying these prior studies to the satisfaction of life of the Korean elderly, the elderly with low subjective class consciousness, which indicates their relative position through comparison with others, have objective factors such as income level, education level and housing retention. Regardless, we can assume that this elderly will have lower life satisfaction. Already, studies on the relationship between subjective class consciousness and life satisfaction have shown that low class consciousness has an impact on low life satisfaction (Yoon \& Kim, 2008; Lee \& Lee, 2017).

In particular, the elderly generation in South Korea values face-to-face relationships and feels more loss of inequality than other generations. However, there are very few studies that compare and analyze the significance and size of the subjective class consciousness perceived by the elderly generation on life satisfaction.

Thus, the purpose of this study is to analyze the effect of subjective class consciousness perceived by elderly people over 65 years of age on life satisfaction. For this purpose, hierarchical regression analysis will be conducted using the 17th data of the Korea Labor Panel (2014). This study is expected to contribute theoretically and offer potential policies to the improvement of elderly life satisfaction according to the cultural characteristics of Korea.

\section{Literature Review}

\subsection{Satisfaction of the Elderly's Life from the Perspective of the Social Comparative Approach}

In general, life satisfaction of the elderly is considered an indicator of successful aging (Berg, 2008). In this respect, many scholars have observed the satisfaction of the elderly's life and measured and discussed it in various aspects. In particular, research on consumption among economic characteristics has been actively conducted as a main influential variable on the satisfaction of life of the elderly (Kim et al., 2016; Jung \& Moon, 2018). Kim and Yoo (2012) also conducted a longitudinal study on the relationship between elderly life satisfaction and income trajectory.

According to a study by Kim and Kwon (2013), the effects of job characteristics on the life satisfaction of the elderly were examined. It was shown that the direct and indirect effects of work income, working days, physical work days and content job demands on job satisfaction were mediated by job satisfaction. In addition, Lee (2016) examined the relationship between employment, welfare, and quality of life in old age, suggesting that in order for the labor of the elderly to be directly related to the quality of life, it must be combined with the conditions of high level of welfare of the elderly and the guarantee of a stable income. Moreover, many previous studies have found that the objective living conditions of the elderly are closely related to life satisfaction through empirical analysis.

However, scholars embracing the theory of social comparison present a different view. The impact of the conditions of objective living on subjective quality of life is not deterministic and is limited. Happiness depends on relative standards, more precisely on the gap between the individual's actual situation and by only a few of the criteria he is applying. This theory is called comparison theory, discrepancy theory, or judgment theory (Schyns, 2000). Social comparison theory was first proposed by the American social psychologist Leon Festinger (1954). In analyzing the motivations and purposes of comparisons, he found that people use comparisons as a means of relative evaluation.

He also found that comparisons generally target people of a similar standard of living, and that the process of comparison shows a change in coordinating similar people, lifestyles, and ways of thinking. Subsequent studies pointed out that in addition to similar comparisons suggested by the Festinger, there are comparisons due to various motivations such as upward comparison and downward comparison (Jang, 2009; Kim, 2013). Upward comparison, for example, has the characteristic of aspirations for achievement and motivation to set goals in order to keep up with living standards, while downward comparison allows people to 
evaluate their condition based on people who are considered to be less than themselves in terms of self-esteem and other factors (Taylor, Wayment \& Carrillo, 1996; Nguyen et al., 2019). Similarly, Luttmer (2005) and Ferrer-i-Carbonell (2005) studied on the short-term and long-term comparisons. Short-term comparisons are those with close associates, while long-term comparisons are either those that are richer (upward comparisons) or poorer (downward comparisons). In this way, the setting of reference groups has a very important meaning as a scale for evaluating one's situation (Hyman, 1960). The reference group established has a significant impact on the subjective social status (SSS) that an individual perceives.

Stouffer et al. (1949), who studied the subjective wellbeing of World War II veterans, pointed out that AfricanAmerican soldiers in the southern United States are happier than African-American soldiers in the north. This was explained by the fact that African-American soldiers felt less discomfort because the South had developed less than the North. In regards to this, this current study focuses on social comparative theory and also on the effect of subjective class consciousness on life satisfaction because happiness tends to change relatively. Easterlin (1974) found that the relative rise in objective gross income (GDP) and the increase in absolute income have limits in promoting happiness.

Although there is no clear orthodoxy about the relationship between income and happiness, scholars support the law of diminishing happiness that reduces the amount of happiness promoted as income increases (Layard, 2005; Inglehart et al., 2008). Happiness is relative because people have a desire to gain an edge in the status race, which subjectively compares their position with others. It is more important to interpret the conditions and how to position them in society than the objective and absolute conditions themselves (Lee \& Lee, 2017; Lee \& Kim, 2019; Jalal et al., 2019). In particular, the Korean society experienced a phenomenon in which subjective class consciousness changed negatively and happiness greatly decreased under the widening inequality through the 1997 financial crisis on a cultural foundation with a strong belief in egalitarianism. (Lee \& Lee, 2017). Therefore, it can be inferred that the subjective class consciousness of the elderly reflecting the result of social comparison will have a significant effect on life satisfaction.

\subsection{Subjective Class Recognition of the Elderly}

Inequality is also actively discussed in Korean society, where the polarization of hierarchical structure and the fixation of hierarchical order are taking place. The academic community focused mainly on analyzing the causes and consequences of social inequality at the structural and institutional level (Lee, 2008; Son, 2009; Lee, 2013; Nam,
2015; Seo, 2016; Lee, 2016). In contrast, subjective class consciousness reflects the conscious dimension of social inequality. How an individual view his situation does not necessarily correspond to objective indicators. Therefore, in order to understand social inequality as a whole, it is necessary to consider both the individual's feelings and their emotions. This is because the individual's subjective sense of hierarchy and expectation of status increase are examples of personal responses to the current hierarchy.

Subjective class consciousness comprehensively shows life-time achievements and captures unobserved aspects as well as observed aspects of socioeconomic resources (Demakakos et al., 2008). Not captured in traditional socioeconomic status, but in subjective class consciousness are the neighbors, educational experience, meaningful social relationships, employment security, insecurity and career. Subjective class consciousness can also capture the relative position in the community with which the individual is associated, which is considered to have a more decisive and closer effect on the well-being of life than any other variable of objective socioeconomic status. (Marmot, 2004; Wilkinson \& Pickett, 2006).

In general, the subjective class consciousness of the elderly is reported to be lower than in other generations. In particular, the subjective social status of retired seniors was very low compared to those in managerial and professional occupations. This is largely influenced by the age that active social life is no longer possible at lower income levels. In other words, the loss of status of the elderly in the labor market is an important cause of older people's low recognition of their status in society. However, subjective class consciousness can be very different in older generations, and older people with lower subjective social status have poorer mental and physical health than those who do not (Demakakos et al., 2008). Previous studies show that subjectively measured social status can be a strong predictor of health, especially for the elderly.

Low subjective social status was associated with difficulties in IADL and lower physical activity in a study of older adults in Taiwan ( $\mathrm{Hu}$ et al., 2005). Additionally, in a study of older Americans, negative subjective class consciousness had more impact on stress-induced cortisol production than objectively measured socioeconomic status (Wright \& Steptoe, 2005). According to Wang and Vanderweele (2011), who conducted a time-series study of the relationship between subjective social status and health, elderly people with low subjective social status had a significantly increased risk of long-term functional decline. The relationship between subjective belief that things are worse than others and poor health outcome was significant even after accounting for controlling demographic characteristics, objective socioeconomic status and medical environment and health status. After all, low subjective 
social status is not only a measure of socioeconomic pain, but also an important measure of health risk as well.

In this respect, it is very important to examine the subjective class perceptions of Korean elderly and their effects. Despite the very high-income poverty rates of the elderly in Korea, there have been questions about whether their economic status is very poor compared to the working age generation (Lee, 2015). Since poverty is usually based on a single income baseline that applies to all citizens, material resources other than income are likely to be overlooked (Kim \& Seo, 2013). As of 2015, the average net assets of households over the age of 60 were 312.57 million, more than those in their 30s (188.6 million) and those in their 40s (267.72 million), while the proportion of financial liabilities held in their 30s (68.2) and those in their 40s (70.1\%) (National Statistical Office, 2015). Thus, it can be observed that economic well-being experienced by the elderly may be different from the poverty rates that are shown.

The poverty rate, measured on a single income baseline, does not reflect the difference in utility across ages. Even if the monthly income is the same, it is hard to say that the benefits of households with young children and households with the elderly are being achieved equally. This is because the amount of income required for the realization of skills varies depending on the social environment and various characteristics of the individual (Kim \& Seo, 2013). Therefore, it is important for the Korean elderly to understand their socioeconomic status and how their subjective perception affects happiness.

\section{Research Methods}

\subsection{Research Data}

The study used 17th data (2014) of the Korean Labor and Income Panel Study. The Korea Labor Panel is a panel data that conducts an annual survey of 5,000 households and 13,000 household members living in the country, except Jeju Island. The Korean Labor Panel includes information on subjective class consciousness, income level, education level, state of economic activity, housing type, health status and marital status. A total of 1,974 samples were taken into the analysis after removing missing values and extracting the elderly aged 65 and over.

\subsection{Main Variables}

The dependent variable in this study was life satisfaction. The Korean Labor Panel's life satisfaction was asked on a five-point scale: family income satisfaction, leisure life satisfaction, residential environment satisfaction, family relationship satisfaction, relative relationship satisfaction, social intimacy satisfaction, and overall satisfaction. In this study, recoding was carried out so that the higher the value, the higher the satisfaction (very dissatisfied $=0$, very satisfied $=4$ ), and then the numbers were summed against the total rating scale (minimum value $=0$, maximum value $=28$ ). Prior to the reliability analysis, the Cronbach's alpha value was as high as .894 .

The independent variable of this study was subjective hierarchy. The Korean Labor Panel measures subjective class consciousness on a six-point scale with the question: Where do you think your socio-economic status (considering income, occupation, education, property, etc.) belongs? (Top level $=1$, upper level $=2$, upper middle layer $=3$, lower middle layer $=4$, lower layer $=5$, lowest layer $=6$ ).

In this study, subjective class consciousness was classified into the upper middle, lower middle, lower and lowest layers and used for analysis. Unlike previous studies that classify the upper, middle, and lower classes, the reasons for classifying the upper, middle, lower, and lowest levels were only $17(0.9 \%)$ who perceived themselves as upper or uppermost among the elderly samples used in the analysis.

Finally, the control variables of this study are income level, education level, economic activity status, housing type, gender, age, marital status, health status and religion, which many studies indicated to be related to life satisfaction. As defined by the Organization for Economic Co-operation and Development (OECD), less than $50 \%$ of household disposable median income is divided among the poor, $50 \%-150 \%$ of the middle class, and more than $150 \%$ of the middle class. The level of education distinguished between high school and below and college and above, and economic activity classified paid labor participation and non-paid labor, and housing type divided self, rent, rent, and others. Ages were classified as 65-74 years old and 75 years old or older, and marital status classified married, spouse, separated, divorced, bereavement and others.

The state of health used a 5-point scale in the analysis (very good $=0$, very bad $=4$ ), and religion was classified as either religious or nonreligious. The analysis framework of this study is summarized in Table 1.

\subsection{Analysis Method}

This study conducted hierarchical multiple regression test to analyze the significance and magnitude of the effect of subjective class consciousness on life satisfaction. Hierarchical regression is an analysis method that allows variables to be sequentially entered into the analysis to compare relative magnitudes of influence. This paper first analyzes the gender, age, marital status, health status and religion of the elderly according to demographic characteristics. Finally, subjective hierarchy was put into analysis. Prior to this, all the independent and control variables were introduced into the multiple regression model, and no problems of multicollinearity were found. 
Table 1: Operational Definition of Variables and Methods of Measurement

\begin{tabular}{|c|c|c|}
\hline Division & Variable name & Definition and measurement of variables \\
\hline $\begin{array}{l}\text { Dependent } \\
\text { variable }\end{array}$ & Life satisfaction & Continuous variable (minimum value $=0$, maximum value $=28$ ) \\
\hline $\begin{array}{l}\text { Independent } \\
\text { variable }\end{array}$ & Subjective hierarchy & $\begin{array}{c}\text { Upper middle layer or higher }=0, \text { middle lower layer }=1 \text {, } \\
\text { lower layer }=2, \text { lowest layer }=3\end{array}$ \\
\hline \multirow{9}{*}{ Control variable } & Income level & Impoverished Class $=0$, Middle Class $=1$, Middle Class Above $=2$ \\
\hline & Education level & High school and below $=0$, College and above $=1$ \\
\hline & Economic activity & Paid work participation $=0$, No paid work participation $=1$ \\
\hline & Housing type & Self $=0$, Charter/rent and others $=1$ \\
\hline & Gender & Male $=0$, Female $=1$ \\
\hline & Age & 65 years old or older $\sim 74$ years old $=0,75$ years old or older $=1$ \\
\hline & Marital status & Married $=0$, Divorce, bereavement, separation $=1$ \\
\hline & Health status & Continuous variable (minimum value $=0$, maximum value $=4$ ) \\
\hline & Religion & No religion $=0$, religion $=1$ \\
\hline
\end{tabular}

\section{Research Results}

\subsection{General Characteristics of the Sample}

The general characteristics of the elderly sample used in this paper are summarized in Table 2. First, the average life satisfaction was 15.704 (standard deviation $=3.5785$ ). The subjective consciousness was $206(10.4 \%)$ in the upper and upper middle, $760(38.5 \%)$ in the lower and middle, 647 $(32.8 \%)$ in the lower and $361(18.3 \%)$ in the lowest.

The income level was 906 (45.9\%) for the poor, $887(44.9 \%)$ for the middle class, and $181(9.2 \%)$ for the middle class and above. The level of education was 1,777 students $(90.0 \%)$ below high school, 197 students $(10.0 \%)$ above college, and economic activity status was $676(34.2 \%)$ who participated in paid labor, and $1,298(65.8 \%)$ who did not participate in paid work. The housing type were 1,456 inhabitants $(73.7 \%)$, charter and other 518 people $(26.3 \%)$.

The gender was 1,155 males (58.5\%), and 819 females (41.5\%). The marital status was $1,033(52.3 \%)$ married and $941(47.7 \%)$ divorced or separated. The religious status was $901(45.6 \%)$ without religion and 1,073 (54.4\%) with religion.

The above descriptive statistics show that the elderly people's life satisfaction is not as high as the median (14 points), while the proportion of those who consider themselves as lower or lowest is higher than half. The percentage of the elderly who consider themselves lower or lowest was higher than that of the poor at the objective level of income. Additionally, many of the elderly who regarded themselves as middle class (middle or middle class) perceived themselves as middle class.

\subsection{Results of Mean Comparison}

Table 3 shows the results of the analysis of the average difference in life satisfaction according to subjective class consciousness, socioeconomic and demographic factors of the sample. As a result, the difference of life satisfaction according to subjective class consciousness proved to be significant $(\mathrm{p}<.05)$. The difference in life satisfaction according to subjective class consciousness was hierarchical in order of upper middle class, middle class, lower class lower level.

On the other hand, life satisfaction according to income class also appeared hierarchically in the order of middle class and above, middle class and then the poor level. The level of education was higher than that of seniors with higher education or higher than the seniors with lower education. The satisfaction of life was higher than the elderly.

In terms of gender, older men were older than the females, and the older ages were from around 65-74. It was also observed that the older wives were older than 75 , and married wives were older than the married spouses. Elderly people with religion had higher life satisfaction than older people without religion.

\subsection{Results of Hierarchical Regression}

The results of analyzing the magnitude of the subjective class consciousness, demographic characteristics and socioeconomic characteristics of the elderly on life satisfaction through hierarchical regression analysis are shown in Table 4. As explained in the research method, the first stage was used to analyze gender, age, marital status, health status and religion, which are demographic 
Table 2: General characteristics of the sample

\begin{tabular}{|c|c|c|}
\hline Division & Variable name & Definition and measurement of variables \\
\hline Dependent variable & Life satisfaction & Mean $=15.704$, standard deviation $=3.575$, minimum $=0$, maximum $=28$ \\
\hline Independent variable & $\begin{array}{l}\text { Subjective } \\
\text { hierarchy }\end{array}$ & $\begin{array}{c}\text { More than upper middle }=206(10.4 \%), \text { middle and lower }=760(38.5 \%), \\
\text { lower }=647(32.8 \%), \text { lowest }=361(18.3 \%)\end{array}$ \\
\hline \multirow{9}{*}{ Control variable } & Income level & $\begin{array}{c}\text { Poor }=906(45.9 \%), \text { middle class }=887(44.9 \%) \\
\text { Middle class and above }=181 \text { people }(9.2 \%)\end{array}$ \\
\hline & Education level & $\begin{array}{l}\text { High school and below }=1,777 \text { students }(90.0 \%) \\
\text { college and above }=197 \text { students }(10.0 \%)\end{array}$ \\
\hline & Economic activity & Paid labor participation $=676(34.2 \%)$, paid labor absent $=1,298(65.8 \%)$ \\
\hline & Housing type & Self $=1,456(73.7 \%)$, charter $/$ rent and others $=518(26.3 \%)$ \\
\hline & Gender & Male $=1,155(58.5 \%)$, Female $=819(41.5 \%)$ \\
\hline & Age & $\begin{array}{c}65 \text { years old or older }-74 \text { years old or less }=1,063(53.9 \%) \\
75 \text { years old or older }=911 \text { people }(46.1 \%)\end{array}$ \\
\hline & Marital status & Married $=1,033(52.3 \%)$, divorce, bereavement, separation = $941(47.7 \%)$ \\
\hline & Health status & Mean $=2.240$, standard deviation $=.896$ \\
\hline & Religion & No religion $=901(45.6 \%)$, Religion $=1,073(54.4 \%)$ \\
\hline
\end{tabular}

Table 3: Differences in Life Satisfaction according to Subjective Class Awareness and Demographic and Socioeconomic Characteristics of the Elderly

\begin{tabular}{|c|c|c|c|c|c|c|}
\hline Variable & & Frequency & Medium & $\begin{array}{l}\text { Standard } \\
\text { Deviation }\end{array}$ & F/t & Post test \\
\hline \multirow{4}{*}{$\begin{array}{l}\text { Subjective } \\
\text { hierarchy }\end{array}$} & $\begin{array}{l}\text { Upper middle and } \\
\text { above }\end{array}$ & 206 & 18.738 & 3.073 & \multirow{4}{*}{$247.329^{\star \star *}$} & \multirow{4}{*}{$\begin{array}{c}\text { Upper middle and } \\
\text { above> } \\
\text { Middle Lower> Lower } \\
\text { Levels> } \\
\text { Lowest layer }\end{array}$} \\
\hline & Middle lower & 760 & 16.826 & 2.808 & & \\
\hline & Lower levels & 647 & 15.257 & 2.929 & & \\
\hline & Lowest layer & 361 & 12.410 & 3.673 & & \\
\hline \multirow{3}{*}{ Income level } & Poverty & 906 & 14.436 & 3.728 & \multirow{3}{*}{$127.667^{* \star *}$} & \multirow{3}{*}{$\begin{array}{l}\text { Middle class and above } \\
\text { Middle Class> Poverty }\end{array}$} \\
\hline & Middle class & 887 & 16.583 & 3.042 & & \\
\hline & $\begin{array}{l}\text { Middle class and } \\
\text { above }\end{array}$ & 181 & 17.740 & 2.933 & & \\
\hline \multirow{2}{*}{$\begin{array}{l}\text { Education } \\
\text { level }\end{array}$} & $\begin{array}{l}\text { High school or } \\
\text { below }\end{array}$ & 1777 & 15.487 & 3.554 & \multirow[t]{2}{*}{$-8.230^{* \star *}$} & \multirow{2}{*}{$\begin{array}{l}\text { College or above> High } \\
\text { school or below }\end{array}$} \\
\hline & College or above & 197 & 17.660 & 3.156 & & \\
\hline \multirow{2}{*}{$\begin{array}{l}\text { Economic } \\
\text { activity }\end{array}$} & $\begin{array}{l}\text { Paid labor } \\
\text { participation }\end{array}$ & 676 & 16.274 & 3.074 & \multirow[t]{2}{*}{$5.486^{* * *}$} & \multirow{2}{*}{$\begin{array}{c}\text { Paid Labor } \\
\text { Participation }>\text { No Paid } \\
\text { Labor }\end{array}$} \\
\hline & No paid labor & 1298 & 15.407 & 3.778 & & \\
\hline \multirow[b]{2}{*}{ Housing type } & Self & 1455 & 16.299 & 3.325 & \multirow[b]{2}{*}{$12.819^{\star \star *}$} & \multirow[b]{2}{*}{ charter/rent and others } \\
\hline & $\begin{array}{l}\text { charter/rent and } \\
\text { others }\end{array}$ & 517 & 14.045 & 3.729 & & \\
\hline \multirow{2}{*}{ Gender } & Male & 1155 & 16.262 & 3.458 & \multirow{2}{*}{$8.389^{* * *}$} & \multirow{2}{*}{ Male> female } \\
\hline & Female & 819 & 14.916 & 3.592 & & \\
\hline \multirow{2}{*}{ Age } & $65-74$ years old & 1063 & 16.038 & 3.361 & \multirow{2}{*}{$4.465^{\star * *}$} & \multirow{2}{*}{$\begin{array}{c}65-74 \text { years old }> \\
75 \text { years old or older }\end{array}$} \\
\hline & 75 years old or older & 911 & 15.314 & 3.774 & & \\
\hline \multirow[b]{2}{*}{ Marital status } & Married & 1033 & 16.535 & 3.243 & \multirow[b]{2}{*}{$11.163^{* \star *}$} & \multirow{2}{*}{$\begin{array}{c}\text { Married> } \\
\text { Divorce, bereavement, } \\
\text { separation }\end{array}$} \\
\hline & $\begin{array}{l}\text { Divorce, } \\
\text { bereavement, } \\
\text { separation }\end{array}$ & 941 & 14.791 & 3.700 & & \\
\hline \multirow[b]{2}{*}{ Religion } & No religion & 901 & 15.457 & 3.469 & \multirow[b]{2}{*}{$-2.823^{\star *}$} & \multirow[b]{2}{*}{$\begin{array}{l}\text { Has religion> } \\
\text { No religion }\end{array}$} \\
\hline & Has Religion & 1073 & 15.911 & 3.651 & & \\
\hline \multicolumn{2}{|l|}{ Sum } & & & & & \\
\hline
\end{tabular}

${ }^{*} \mathrm{p}<.05,{ }^{* *} \mathrm{p}<.01,{ }^{* * *} \mathrm{p}<.001$ 
characteristics. Activity status and dwelling type were used for the second stage of the analysis. Finally, in the third stage, subjective hierarchy was put into the analysis as well. The significance of the regression model at each stage was $p$ $=.000$ and no problem was found.

First, the demographic variables introduced in Stage 1 accounted for $16.7 \%$ of the elderly's life satisfaction. Marital status ( $\beta=-.215)$, health status $(\beta=-.332)$, and religion status $(\beta=.081)$ had a significant effect on the life satisfaction of the elderly. Specifically, the divorce, separation, and bereavement were found to be significantly lower in the elderly people's life satisfaction as they were divorced, separated, and bereaved.

Next, the variables of socioeconomic characteristics introduced in the second stage significantly increased the explanatory power of $9.2 \%$ in addition to the life satisfaction of the elderly. Gender $(\beta=.087)$, age $(\beta=.063)$, marital status $(\beta=-.163)$, health status $(\beta=-.276)$ and religion status $(\beta=.072)$. At the same time, income level, education level $(\beta$ $=.082)$, economic activity status $(\beta=.049)$ and housing type ( $\beta=-.180)$ had a significant effect on the life satisfaction of the elderly. In terms of income level, the life satisfaction of the middle class $(\beta=.208)$ and the middle-class group ( $\beta=.170)$ was significantly higher than that of the poor. In general, elderly people with high socioeconomic status such as high-income level and education level, participation in paid labor, and self-owning have high life satisfaction.

Lastly, the subjective class consciousness variable introduced in step 3 increased $8.4 \%$ of the explanatory power of elderly people's life satisfaction. In the second stage, the additional explanatory power was $4.1 \%$ when only the income level was separately analyzed. Through this, it can be confirmed that the explanatory power of the life satisfaction of the elderly in subjective class consciousness is relatively large compared to the objective income level.

Finally, the research model of this paper explained $34.3 \%$ of life satisfaction of the elderly. In the three-stage model, all variables except education level and economic activity had a significant effect. In the subjective class consciousness, the life satisfaction of the lower middle ( $\beta=-.172)$, lower layer $(\beta=-.298)$ and the lowest layer $(\beta=-.469)$ was significantly lower than that of the upper middle layer. The magnitude of the influence was generally higher than other demographic and socioeconomic variables.

\section{Conclusion}

This study analyzed the effects of subjective class consciousness on life satisfaction in the situations where the high suicide rate and low quality of life of Korean elderly were emerging as social problems. Subjective class consciousness affects life satisfaction while controlling the influence of demographic factors such as gender, age, marital status, health status, religion, and socioeconomic factors such as income level, education level, economic activity status and housing type. We aimed to analyze the significance of the impact and the amount of explanatory power in this setting. For this purpose, the Korean Labor Panel 17th (2014) data were used to sample the elderly aged 65 and older and oneway ANOVA and hierarchical regression analysis were performed. The results of the main analysis are summarized as follows.

First, as a result of analyzing the life satisfaction of the elderly, the average value (15.704) was similar to the median value (14.000) and could not be seen as high. In addition, as a result of analyzing the subjective class consciousness of the elderly, many considered themselves as the lower or the lowest of the classes. Most elderly people who did not perceive themselves as either lower or lowest class were also recognized as middle and lower class. This shows that the satisfaction of life experienced by the elderly in Korea is not high and that the subjective class consciousness is also negative. This shows that the economic well-being of the Korean elderly is not good even considering the limitations of the income poverty measure pointed out by Kim and Seo (2013). The low life satisfaction and negative subjective class consciousness of the Korean elderly seems to be related to the low life satisfaction and high suicide rate indicated by Kim (2016) and OECD (2017).

Second, according to the subjective class consciousness, there was a significant difference in the life satisfaction of the elderly. Older people who regarded themselves as the lowest had the lowest satisfaction with life. The satisfaction of life of the elderly who considered themselves above the middle class was the highest. Given the inconsistency between objective income levels and subjective class consciousness, it can be assumed that a subjective assessment of one's socioeconomic status can have a more significant impact on life satisfaction. This supports the results of previous studies (Adler et al., 2008; Franzini \& Fernandez-Escquer, 2006; Ghaed \& Gallo, 2007; Hu et al., 2005), which show that there are differences in mental and physical health depending on subjective class consciousness. It can be seen as.

Third, subjective class consciousness explained $8.4 \%$ of life satisfaction of the elderly. This was similar to the extent that socioeconomic variables such as income level, education level, economic activity status and housing type explained the satisfaction of the elderly's life $(9.2 \%)$. The level of explanation was much greater than the level of income $(4.1 \%)$ that independently explained the satisfaction of the elderly's life. In addition, the magnitude of the relative influence on the life satisfaction of the subjective class consciousness confirmed through the beta value was larger than other variables. It supports Stouffer et al. (1949) and Easterlin (1974) previous studies in that subjective 
Table 4: Hierarchical Regression Results

\begin{tabular}{|c|c|c|c|c|c|c|c|c|c|}
\hline \multirow{2}{*}{ Division } & \multicolumn{3}{|c|}{ Model 1} & \multicolumn{3}{|c|}{ Model 2} & \multicolumn{3}{|c|}{ Model 3} \\
\hline & B(S.E) & $\beta$ & $\mathrm{t}$ & B(S.E) & $\beta$ & $\mathbf{t}$ & B(S.E) & $\beta$ & $t$ \\
\hline (Constant) & $\begin{array}{c}18.148 \\
(.677) \\
\end{array}$ & & $26.805^{* * *}$ & $\begin{array}{l}15.355 \\
(.709) \\
\end{array}$ & & $21.667^{* * *}$ & $\begin{array}{c}17.215 \\
(.711)\end{array}$ & & $24.208^{* * *}$ \\
\hline $\begin{array}{l}\text { Gender } \\
\text { (By: men) }\end{array}$ & $\begin{array}{l}.396 \\
(.255)\end{array}$ & .055 & 1.556 & $\begin{array}{l}.628 \\
(.243)\end{array}$ & .087 & $2.587^{*}$ & $\begin{array}{l}.660 \\
(.229)\end{array}$ & .091 & $2.884^{* *}$ \\
\hline $\begin{array}{l}\text { Age group } \\
\text { (By: 65-74 years } \\
\text { old) }\end{array}$ & $\begin{array}{l}.174 \\
(.155)\end{array}$ & .024 & 1.122 & $\begin{array}{l}.451 \\
(.155)\end{array}$ & .063 & $2.916^{* *}$ & $\begin{array}{l}.407 \\
(.146)\end{array}$ & .057 & $2.793^{\star *}$ \\
\hline $\begin{array}{l}\text { Marital status } \\
\text { (By: married) }\end{array}$ & $\begin{array}{c}-1.536 \\
(.249)\end{array}$ & -.215 & $-6.180^{* * *}$ & $\begin{array}{c}-1.168 \\
(.237)\end{array}$ & -.163 & $-4.922^{* * *}$ & $\begin{array}{l}-.917 \\
(.224)\end{array}$ & -.128 & $-4.086^{* * *}$ \\
\hline Health & $\begin{array}{l}-1.325 \\
(.088) \\
\end{array}$ & -.332 & $-15.106^{* * *}$ & $\begin{array}{l}-1.101 \\
(.087) \\
\end{array}$ & -.276 & $-12.607^{* * *}$ & $\begin{array}{l}-.808 \\
(.084) \\
\end{array}$ & -.202 & $-9.573^{* * *}$ \\
\hline $\begin{array}{l}\text { Religion } \\
\text { (Reference: no } \\
\text { religion) }\end{array}$ & $\begin{array}{l}.583 \\
(.151)\end{array}$ & .081 & $3.847^{* * *}$ & $\begin{array}{l}.515 \\
(.144)\end{array}$ & .072 & $3.587^{* * *}$ & $\begin{array}{l}.519 \\
(.135)\end{array}$ & .072 & $3.836^{\star \star \star}$ \\
\hline \multicolumn{10}{|c|}{ Income level (By: poverty level) } \\
\hline Middle class & & & & $\begin{array}{l}1.496 \\
(.159) \\
\end{array}$ & .208 & $9.425^{\star * *}$ & $\begin{array}{l}.761 \\
(.157) \\
\end{array}$ & .106 & $4.847^{* \star \star}$ \\
\hline $\begin{array}{l}\text { Middle class and } \\
\text { above }\end{array}$ & & & & $\begin{array}{l}2.102 \\
(.272)\end{array}$ & .170 & $7.727^{* * *}$ & $\begin{array}{l}.975 \\
(.269)\end{array}$ & .079 & $3.626^{\star * *}$ \\
\hline $\begin{array}{l}\text { Education level } \\
\text { (standard: high } \\
\text { school and } \\
\text { below) } \\
\end{array}$ & & & & $\begin{array}{l}.975 \\
(.246)\end{array}$ & .082 & $3.959^{* * *}$ & $\begin{array}{l}.433 \\
(.237)\end{array}$ & .036 & 1.826 \\
\hline $\begin{array}{l}\text { Economic activity } \\
\text { (By: paid work } \\
\text { participation) }\end{array}$ & & & & $\begin{array}{l}.366 \\
(.164)\end{array}$ & .049 & $2.225^{*}$ & $\begin{array}{l}.169 \\
(.156)\end{array}$ & .022 & 1.089 \\
\hline $\begin{array}{l}\text { Housing type } \\
\text { (By self) }\end{array}$ & & & & $\begin{array}{l}-1.463 \\
(.164) \\
\end{array}$ & -.180 & $-8.910^{* * *}$ & $\begin{array}{l}-.770 \\
(.161) \\
\end{array}$ & -.095 & $-4.781^{* * *}$ \\
\hline \multicolumn{10}{|c|}{ Subjective hierarchy (by: upper middle class) } \\
\hline Mid-tier & & & & & & & $\begin{array}{r}-1.262 \\
(.240) \\
\end{array}$ & -.172 & $-5.257^{* * *}$ \\
\hline $\begin{array}{l}\text { Low } \\
\text { layer }\end{array}$ & & & & & & & $\begin{array}{r}-2.272 \\
(.260) \\
\end{array}$ & -.298 & $-8.737^{* * *}$ \\
\hline Lowest layer & & & & & & & $\begin{array}{l}-4.339 \\
(.305)\end{array}$ & -.469 & $-14.220^{* * *}$ \\
\hline $\mathrm{F}$ & \multicolumn{3}{|c|}{$78.721^{* * *}$} & \multicolumn{3}{|c|}{$68.646^{* * *}$} & \multicolumn{3}{|c|}{$78.619^{\star * *}$} \\
\hline $\mathrm{R}^{2}$ change & \multicolumn{3}{|c|}{.167} & \multicolumn{3}{|c|}{.092} & \multicolumn{3}{|c|}{.084} \\
\hline $\mathrm{R}^{2}$ & \multicolumn{3}{|c|}{.167} & \multicolumn{3}{|c|}{.259} & \multicolumn{3}{|c|}{.343} \\
\hline Durbin-Watson & & & & & & & & 1.770 & \\
\hline
\end{tabular}

${ }^{*} \mathrm{p}<.05,{ }^{* *} \mathrm{p}<.01,{ }^{* * *} \mathrm{p}<.001$

class consciousness, which represents the relative socioeconomic status of comparing others with themselves, has a very important effect on elderly people's life satisfaction. As previous studies have shown, low subjective class consciousness negatively affects mental and physical health and hormonal secretion (Hu et al., 2005; Wright \& Steptoe, 2005; Chen et al., 2011).

The results of the analysis suggest that raising the subjective class consciousness of the elderly, as Marmot (2004) and Wilkinson and Pickett (2006) pointed out, may 
be important in improving life satisfaction. Subjective class consciousness has a significant correlation with life satisfaction because the satisfaction of recognition needs has a significant effect on mental health. Moreover, as Ko and Hwang (2013) argued, due to the cultural characteristics of Korean society that place importance on status or face, perceptions of relative and subjective classes through comparison with others have more influence on life satisfaction than large and small incomes.

Therefore, it can be evaluated that policy efforts are needed to improve the subjective social status that Korean elderly are aware of. Specifically, efforts are needed to alleviate inequalities in generations that negatively impact social comparison processes. Indeed, in Korea, the elderly aged 65 or older have a much higher income inequality than the working age of 18-64. As of 2016, the market income Gini coefficient of the elderly generation was .540, which is very high compared to the .309 Gini coefficient of working age generation. This severe income inequality in households is thought to contribute to lowering life satisfaction by making the older people more negative than they actually are.

Thus, in the process of expanding old-age pensions, it is necessary to make efforts to reduce inequality in the elderly generation and to raise the standard of living equally by giving more consideration to the elderly. It is necessary to improve the subjective class consciousness of the elderly by equally guaranteeing a certain level of living by strengthening basic pensions and providing general care services.

\section{References}

Adler, N., Singh-Manoux, A., Schwartz, J., Stewart, J., Matthews, K., \& Marmot, M. G. (2008). Social status and health: a comparison of British civil servants in Whitehall-II with European- and African-Americans in CARDIA. Social Science \& Medicine, 66, 1034-1045.

Appleton, S. M., \& Song, L. (2008). Life Satisfaction in Urban China: Components and Determinants. World Development, $36,2325-2340$.

Berg, A. I. (2008). Life satisfaction in late life: Markers and predictors of level and change among $80+$ year olds. Gothenburg, Sweden: Doctoral dissertation, Department of Psychology, University of Gothenburg.

Clark, A. E., \& Senik, C. (2010). Who compares to whom? The anatomy of income comparisons in Europe. Economic Journal, 120(544), 573-594.

D’Ambrosio, C., \& Frick, J. R. (2007). Income Satisfaction and Relative Deprivation: An Empirical Link. Social Indicators Research, 81(3), 497-519.

Delhey, J., \& Kohler, U. (2008). Where we stand in Europe: citizen perceptions of European country rankings and their influence on subjective well-being. Alber, J., Fahey, T., \& Saraceno, C. (eds.). Handbook of Quality of Life in the Enlarged European Union (1st ed.). London: Routledge. pp. 385-403.

Demakakos, P., Nazroo, J., Breeze, E., \& Marmot, M. (2008). Socioeconomic status and health: the role of subjective status. Social Science \& Medicine, 67, 330-340.

Diener, E., \& Fujita, F. (1995). Resources, personal strivings, and subjective well-being: A nomothetic and idiographic approach. Journal of Personality and Social Psychology, 68, 926-935.

Diener, E., Suh, E., Lucas, R. E., \& Smith, H. L. (1999). Subjective well-being: Three decades of progress. Psychological Bulletin, 125, 276-302.

Easterlin, R. (1974). Does Economic Growth Improve the Human Lot? Some Empirical Evidence. David, P., \& Reder, M. (eds.). Nations and Households in Economic Growth: Essays in Honor of Moses Abramovitz. Cambridge: Academic Press. pp. 89-125

Emmons, R. A. (1986). Personal strivings: An approach to personality and subjective well-being. Journal of Personality and Social Psychology, 51, 1058-1068.

Fernandez, R. M., \& Kulik, J. C. (1981). Multilevel model of life satisfaction: Effects of individual characteristics and neighborhood composition. American Sociological Review, 46(3), 840-850.

Ferrer-i-Carbonell, A. (2005). Income and well-being: An empirical analysis of the comparison income effect. Journal of Public Economics, 89(5-6), 997-1019.

Festinger, L. (1954). A theory of social comparison processes. Human Relations, 7(2), 117-140.

Franzini, L., \& Fernandez-Esquer, M. E. (2006). The association of subjective social status and health in low-income Mexicanorigin individuals in Texas. Social Science \& Medicine, 63, 788-804.

Ghaed, S. G., \& Gallo, L. C. (2007). Subjective social status, objective socioeconomic status, and cardiovascular risk in women. Health Psychology, 26, 668-674.

Jalal, R. N., Zeb, N., \& Fayyaz, U. E. (2019). The Effect of Personality Traits on Employee Job Satisfaction with Moderating Role of Islamic Work Ethics. Journal of Asian Finance, Economics and Business, 6(2), 161-171. https://doi. org/10.13106/jafeb.2019.vol6.no2.161

Hu, P., Adler, N. E., Goldman, N., Weinstein, M., \& Seeman, T. E. (2005). Relationship between subjective social status and measures of health in older Taiwanese persons. Journal of the American Geriatrics Society, 53, 483.

Hyman, H. (1960). Reflections on Reference Groups. The Public Opinion Quarterly, 24(3), 383-396.

Ishida, A., Kosaka, K., \& Hamada, H. (2014). A Paradox of Economic Growth and Relative Deprivation. The Journal of Mathematical Sociology, 38(4), 269-284.

Inglehart, R., Foa, R., Peterson, C., \& Welzel, C. (2008). Development, freedom, and rising happiness: A global perspective (1981-2007). Perspectives on Psychological, 3, 264-285. 
Jang E. Y. (2009). Social Comparison and Supervision. Journal of the Korean Psychological Association: Society and Personality. 23(2), 157-169.

Jeong, M. (2013). The Influence of Self-Respect for Elderly on Social Participation and Life Satisfaction-Focusing on Seoul and Gyeonggi-do, Korea Care Management Research, 9, 15-41.

Jung, M. H., \& Moon, J. S. (2018). A Study on the Effect of Beauty Service of the Elderly on Successful Ageing: Focused on Mediated Effect of Self-esteem. Journal of Asian Finance, Economics and Business, 5(4), 213-223. http://doi. org/10.13106/jafeb.2018.vol5.no4.213

Kang, S. (2010). An Analysis of Determinants of Korean Life Satisfaction. Economic Research, 58(1), 5-36.

Katznelson, I. (1986). Working Class Formation: Constructing Cases and Comparisons. Katznelson, I., \& Zolberg, A. (eds.). Working Class Formation. New Jersey: Princeton University Press. pp. 3-44.

Kim, J. H. (2013). Persuasive Psychology. Seoul, Korea: Communication Books.

Kim, J. \& Gobo, S. (2016). Determinants of Life Satisfaction by Consumption Type of Elderly Households. Aged Welfare Study, 71(4), 477-502.

Kim, K., \& Yoo, J. (2012). Long-term Study on Life Satisfaction and Income Trajectory. Study on Welfare of the Elderly, 58, 163-187.

Kim, M., Song, T., Yoo, Y., Jung, H., Ko, J., Yu, J., Kim, G., \& Kim, S. (2016). 2016 Health and Welfare Policy Demand Survey and Analysis. Sejong, Korea: Korea Institute for Health and Social Affairs.

Kim, M., \& Kwon Y. (2013). Effect of Job Characteristics on Life Satisfaction of Elderly Workers: A Multi-group Analysis of Mediating Job Satisfaction and Gender, Korean Society of Geriatrics, 33(1), 67-84.

Kim, Y. T., \& Seo, J. W. (2013). Poverty: how to fight. Paju, Korea: Hanwool Academy.

Knight, J., \& Gunatilaka, R. (2008). Aspirations, Adaptation and Subjective Well-Being of Rural-Urban Migrants in China. Economics Series Working Papers 381. University of Oxford, Department of Economics.

Knight, J., Song, L., \& Gunatilaka, R. (2009). Subjective wellbeing and its determinants in rural China. China Economic Review, 20(4), 635-649.

Ko, J., \& Hwang, S. (2013). A Study on the Relationship between Characteristics of Social Psychology and Types of Education and Leisure Programs for the Elderly in Korea-Focusing on Jeong, Face, and Gender. Korean Care Management Research, 10, 109-135.

Layard, R. (2005). Happiness: Lessons from a New Science. New York: The Penguin Press.

Lee, J. (2015). Women and Poverty in Korea: Why Poverty in Korea Seen in International Comparison. Social Public Research Institute Issue Paper. 2015-05.
Lee, K., Song, W., Lee J., \& Cho Y. (2010). A Study on the Economic Activities of the Elderly in the Aging Age. Business Management Review, 1(1), 147-162.

Lee, S., \& Hong, K. (2012). Theory of habit formation using subjective satisfaction and test of relative income hypothesis. Social Science Research, 38(3), 1-27.

Lee, S. (2016). A Study on the Relationships of EmploymentWelfare-Life Quality in Old Age: Focusing on 28 OECD Countries. Social Welfare Policy, 43(3), 165-182.

Lee, S. K. (2008). Income Components and Household Income Inequalities after Household Crisis. Labor Policy Research, 8(4), 119-146.

Lee, S. H. (2007). Old Age Depression and Stress. Stress Research, 15(4), 295-301.

Lee, W. (2013). Causes of Increasing Income Inequality in Old Age. Korean Sociology, 47(5), 241-275.

Lee, W. S., \& Kim, B. Y. (2019). The Effects of Career Orientations on Entrepreneurial Satisfaction and Business Sustainability. Journal of Asian Finance, Economics and Business, 6(4), 235248. https://doi.org/10.13106/jafeb.2019.vol6.no4.235

Lee, Y. K., \& Lee, S. J. (2017). A Study on the Effect of Social Class on Happiness: Focusing on the Objective and Subjective Consciousness. Korean Journal of Public Administration, 55(1), 1-30.

Lee, Y. (2016). Relationship between Medical Insurance Burden and Family Income Inequality. Journal of the Korea Contents Association, 16(8), 366-375.

Lim, B., \& Ma G. (2015). Study on the Impact of Economic Differences on Life Satisfaction Compared with Regional Reference Groups. National Land Planning, 50(3), 213-224.

Luttmer, E. (2005). Neighbors as negatives: Relative Earnings and Well-Being. The Quarterly Journal of Economics, 120(3), 963-1002.

Marmot, M. (2004). The Status Syndrome. New York: Henry Holt.

McBride, M. (2001). Relative-income effects on subjective wellbeing in the cross-section. Journal of Economic Behavior and Organization, 45(3), 251-278.

Nam, S. (2015). Features of Korean Household Income and Asset Distribution. Health and Welfare Issue \& Focus, 277, 1-8.

Nguyen, K. T., Duong, T. M., Tran, N. Y., Ha, A. T., \& Phung, Y. N. (2019). The Impact of Emotional Intelligence on Performance: A Closer Look at Individual and Environmental Factors. Journal of Asian Finance, Economics and Business 7(1), 183-193. https://doi.org/10.13106/jafeb.2020.vol7. no1.183

OECD. (2017). Health at a Glance 2017. Paris: OECD Publications.

Persky, J., \& Tam, M.Y. (2006). Local Status and National Social Welfare. Journal of Regional Science. 30, 229-238.

Przeworski, A. (1977). Proletariat into a Class: The Process of Class Formation from Karl Kautsky: The Class Struggle to Recent Controversies. Politics and Society, 7, 343-401. 
Ravallion, M., \& Lokshin, M. (2010). Who cares about relative deprivation. Journal of Economic Behavior and Organization, 73(2), 171-185

Poverty Statistics Yearbook. (2017). Poverty Statistics Yearbook 2017. Sejong, Korea: Korea Institute for Health and Social Affairs.

Ryujia. (2015). Effects of Economic Resources on Happiness: A Study on the Existence of Saturation Points and the Social Comparison Effects. Seoul, Korea: Doctoral dissertation, Department of Sociology, Ewha Woman's University.

Schneider, S. M., \& Schupp, J. (2014). Individual differences in social comparison and its consequences for life satisfaction: Introducing a short scale of the Iowa Netherlands comparison orientationmeasure. SocialIndicators Research, 115(2), 767-789.

Schyns, P. (2000). The relationship between income, changes in income and life-satisfaction in West Germany and the Russian Federation: relative, absolute, or a combination of both? Diener, E., \& Rahz, D.R. (eds.). Social Indicators Research Series: Advances in Quality of Life Theory and Research. Netherlands: Springer. pp. 83-109.

Schwarz, N., \& Strack, F. (1999). Reports of subjective well-being: Judgmental processes and their methodological implications. Kabneman, D., Diener, E., \& Schwarz, N. (eds.). Well-being: The foundations of hedonic psychology. New York: Russell Sage Foundation. pp. 61-84.

Seo, H. W. (2016). Politics of Income Inequality in Korea: Political Causes of Income Inequality since the Late 1990s. Journal of Social Sciences, 47(2), 213-233.

Son B. D. (2009). Inequality Trends and Disassembling Factors of Income in the Elderly. Korean Aging Studies, 29(4), 1445-1461.

Statistics Korea. (2015). 2015 Household Finance and Welfare Survey. Daejeon, Korea: Statistics Office

Stouffer, S. A., Suchman, E. A., DeVinney, L. C., Star, S. A., \& Williams, R. A. (1949). The American Soldie; Adjustment during Army Life. New Jersey: Princeton University Press.

Singh-Manoux, A., Marmot, M. G., \& Adler, N. E. (2005). Does subjective social status predict health and change in health status better than objective status? Psychosomatic Medicine, $67,855-861$.

Taylor, S. E., Wayment, H. A., \& Carrillo, M. (1996). Social comparison, self-regulation, and motivation. Sorrentino, R.M., \& Higgins, E.T. (eds.). Handbook of motivation and cognition, Vol. 3. The interpersonal context. New York: Guilford Press. pp. 3-27.

Thompson, E. (1963). The Making of the English Working Class. London: Victor Gollancz.

Thompson, E. (1978). The Poverty of Theory and Other Essays. London: Merlin Press.

Kikkawa, T., \& Fujihara, S. (2012). Class Awareness in Japan and the U. S. Expansion and Stability. Sociological Theory and Methods, 27(2), 205-224.

Van de Stadt, H., Kapteyn, A., \& Van de Geer, S. (1985). The Relativity of Utility: Evidence from Panel Data. The Review of Economics and Statistics, 67(2), 179-187.

Veenhoven, R. (2002). Why Social Policy Needs Subjective Indicators. Social Indicators Research, 58, 33-45.

Wang, P., \& Vanderweele, T. J. (2011). Empirical Research on Factors Related to the Subjective Well-Being of Chinese Urban Residents. Social Indicators Research, 101, 447-459.

Wilkinson, R. G., \& Pickett, K. E. (2006). Income inequality and population health: a review and explanation of the evidence. Social Science \& Medicine, 62, 1768-1784.

Wright, C. E., \& Steptoe A. (2005). Subjective socioeconomic position, gender and cortisol responses to waking in an elderly population. Psychoneuroendocrinology. 30(6), 582-590.

Yoo, S., Kim, M., Kim, K., Chang, A., Seok, S., \& Kim, N. (2017). What kind of society do we live in? The Life of Koreans through the Better Society Index. Seoul, Korea: Let's go.

Yoon, I., \& Kim, S. (2008). The Effect of Socioeconomic Status and Subjective Class Consciousness on Life Satisfaction -Analysis of the Mediating Effect of Higher Utilization of Premium Leisure, Urban Administration Journal, 21(2), 153-185. 